\title{
Pityriasis rubra pilaris: a rare inflammatory dermatosis
}

\author{
Aine Kelly, Aoife Lally
}

Department of Dermatology, St Vincent's University Hospital, Dublin, Ireland

\section{Correspondence to}

Dr Aine Kelly,

107545606@umail.ucc.ie

Accepted 19 January 2018

\section{DESCRIPTION}

An 18-year-old Caucasian woman presented with a 2-week history of a pruritic rash commencing on the face and spreading distally to the trunk and limbs. There were no associated systemic symptoms. Her medical history was unremarkable and there was a family history of hypothyroidism. Physical examination revealed extensive confluent scaly erythema with islands of sparing on the trunk and scaling of the scalp. There was hyperkeratotic plugging of the hair follicles (figure 1 and figure 2). There was a waxy orange keratoderma affecting the palms and soles with associated painful fissuring (figure 3). A clinical diagnosis of pityriasis rubra pilaris (PRP) was made. Histopathology of involved skin showed focal parakeratosis and orthokeratosis alternating in both horizontal and vertical directions with an underlying perivascular inflammatory infiltrate. The patient had a raised thyroid stimulating hormone (TSH) and normal T4 indicative of subclinical hypothyroidism. Treatment for her skin was initiated with methotrexate and titrated to a dose of $15 \mathrm{mg}$ weekly. There was complete

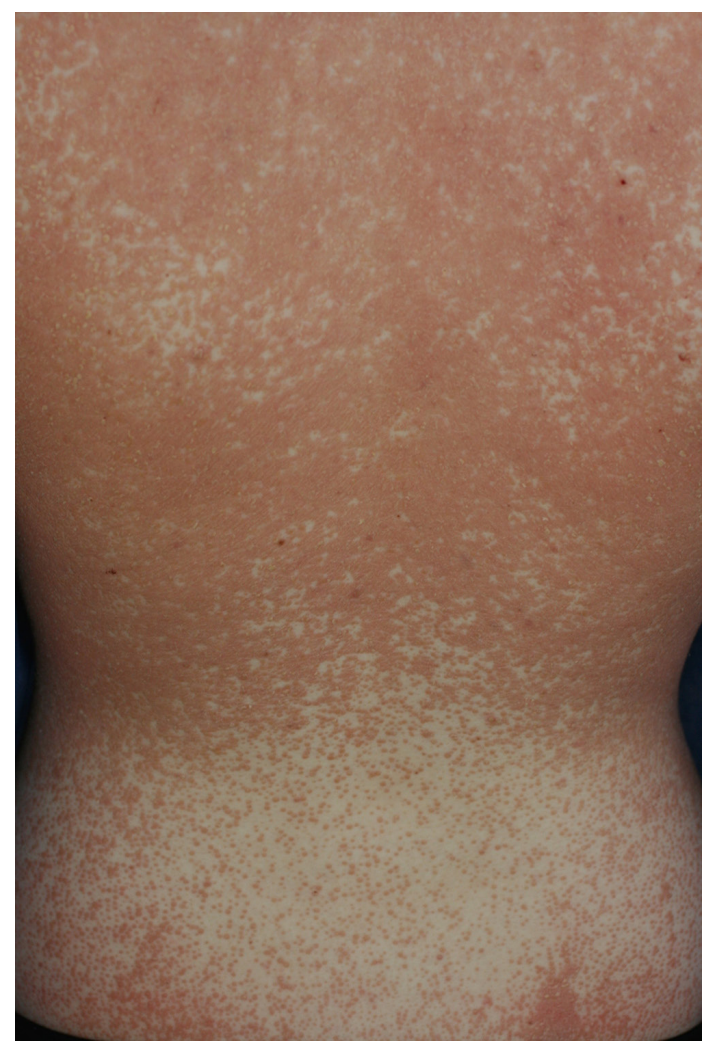

Figure 1 Extensive confluent scaly erythema with follicular accentuation and islands of sparing on the trunk.

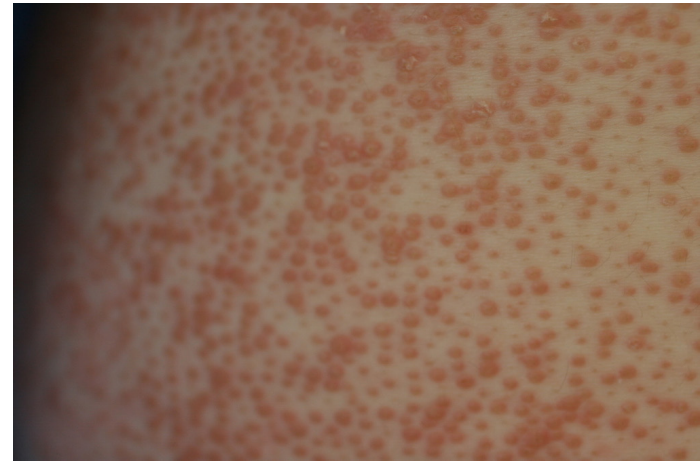

Figure 2 Close-up view of trunk showing small follicular papules with central keratin plug.

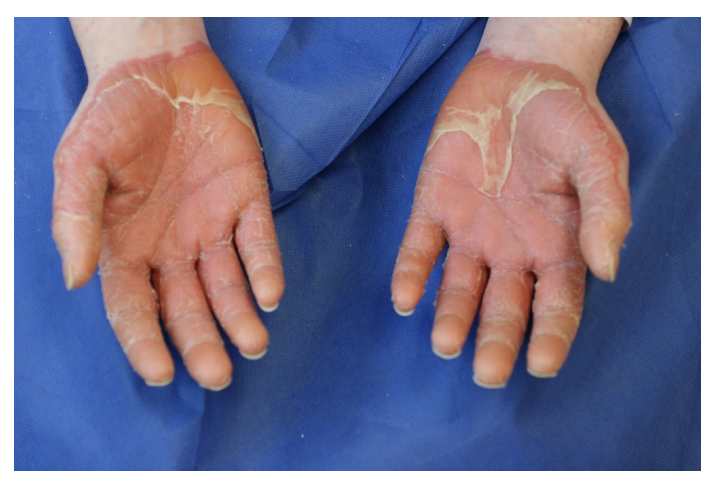

Figure 3 Waxy orange keratoderma affecting the palms and soles with associated painful fissuring.

remission at 16 weeks. This case fits the description of classical adult-type PRP.

PRP is a rare, inflammatory dermatosis of unknown aetiology. The disease commonly presents as a pruritic generalised erythema with islands of sparing. The eruption begins typically in the head region and progresses caudally. The age distribution is bimodal, with onset typically in the first and fifth decades. Griffiths and Ozluer divided PRP into five categories: classical adult type, atypical adult type, classical juvenile type, atypical juvenile type, circumscribed juvenile. In recent times HIV-associated type has been added to the classification system. Our patient fits the description of classical adult-type PRP, although was an atypical presentation given her young age. This variant accounts for 50\% of cases and has a favourable prognosis, resolving in 3 years in approximately $80 \%$ of patients. ${ }^{1}$

PRP has been described in association with hypothyroidism. A retrospective case series of 100 patients diagnosed with PRP found 20\% of patients with PRP to have an associated hypothyroidism. ${ }^{2}$ Four cases in the literature also 
described significant improvement of PRP with hormone correction. ${ }^{3}$ Our patient had subclinical hypothyroidism and a strong family history of hypothyroidism, with her mother and maternal aunts affected.

\section{Learning points}

- Pityriasis rubra pilaris presents classically as a generalised erythema with islands of sparing and an associated keratoderma.

Pityriasis can be associated with hypothyroidism.
Contributors AK prepared this manuscript under the supervision of AL. Both authors approved the final manuscript.

Competing interests None declared.

Patient consent Obtained.

Provenance and peer review Not commissioned; externally peer reviewed.

(C) BMJ Publishing Group Ltd (unless otherwise stated in the text of the article)

2018. All rights reserved. No commercial use is permitted unless otherwise expressly granted.

\section{REFERENCES}

1 Griffiths WA, Ozluer S. [Pityriasis rubra pilaris]. Ann Dermatol Venereol 2001:128:931-4

2 Kohn SR. Pityriasis rubra pilaris. Arch Dermatol 1984;120:995

3 Franzotti AM, Avelar JC, Cardoso TA, et al. Pityriasis rubra pilar and hypothyroidism. An Bras Dermatol 2014;89:497-500

Copyright 2018 BMJ Publishing Group. All rights reserved. For permission to reuse any of this content visit http://group.bmj.com/group/rights-licensing/permissions.

BMJ Case Report Fellows may re-use this article for personal use and teaching without any further permission.

Become a Fellow of BMJ Case Reports today and you can:

- Submit as many cases as you like

- Enjoy fast sympathetic peer review and rapid publication of accepted articles

- Access all the published articles

- Re-use any of the published material for personal use and teaching without further permission

For information on Institutional Fellowships contact consortiasales@bmjgroup.com

Visit casereports.bmj.com for more articles like this and to become a Fellow 